This is the accepted version of an article to be published by Taylor and Francis in South Asian History and Culture. Please refer to the published version when citing: http://www.tandfonline.com/loi/rsac20\#.V5Yrj krKUk

Accepted Version downloaded from SOAS Research Online: http://eprints.soas.ac.uk/22691/

\title{
Borderland Historiography in Pakistan
}

\section{James Caron}

South Asian Languages and Cultures, SOAS, University of London, London, UK

james.caron@soas.ac.uk 
This is the accepted version of an article to be published by Taylor and Francis in South Asian History and Culture. Please refer to the published version when citing: http://www.tandfonline.com/loi/rsac20\#.V5Yrj krKUk

Accepted Version downloaded from SOAS Research Online: http://eprints.soas.ac.uk/22691/

\title{
Borderland Historiography in Pakistan
}

\begin{abstract}
In this article I survey historical writing related to the twentieth-century Afghan-Pakistan frontier, particularly Pashtun-majority locations in KhyberPakhtunkhwa: the former Northwest Frontier Province. I focus on works that help conceptualize history beyond issues of political economy. Some locate themselves solely in the Anglophone academy, but this is not intended as a complete survey of their field. Rather, I place those works in dialogue with, and prioritize, eclectic histories that are both 'about' and 'of' the borderland; and I discuss this combined field with reference to other scholarly work on 'thinking from borders' in both the political-economic and intellectual-cultural senses. My goal is to intervene in the second set of borders, to disrupt boundaries between global academic culture and 'other' intellectual milieus. Taking tazkiras and autobiographies as examples, I argue that genres of writing from regions heavily fragmented by imperial bordering, among other factors, are social theory in action, not just representation for historians to appropriate. Engaging border history genres and taking seriously the insight they offer requires a willingness to engage the webs of social commitments that produced these works: to work in contribution to their milieus rather than merely writing about them.
\end{abstract}

Keywords: Pakistan; historiography; borderlands; border thinking; decoloniality

\section{Introduction:}

This article is not a rethinking of positive history, but rather is an exploration of the intellectual contours of 'border historiography’ related to the Afghan-Pakistan border region since 1900. By this term, I mean recent field-defining work in borderland history related to the Afghan-Pakistan frontier; but I prioritize work that is both 'in' and 'of' that region: how intellectuals in the borderland have represented their society. Like Nile Green's volume Afghan History Through Afghan Eyes, a history of knowledge that inspires me here, I do not argue that 'indigenous’ sources produce somehow 'truer’ history, but rather look at what texts do. ${ }^{\mathrm{i}}$ In contrast to that volume, the texts I discuss 
This is the accepted version of an article to be published by Taylor and Francis in South Asian History and Culture. Please refer to the published version when citing: http://www.tandfonline.com/loi/rsac20\#.V5Yrj krKUk

Accepted Version downloaded from SOAS Research Online: http://eprints.soas.ac.uk/22691/

are recent, from milieus I spent time in and to which I have multiple attachments. I return to these attachments in greater depth in my conclusion. But for now: I cannot treat texts written for the British or North American academy as carriers of knowledge transcendent of context while treating others as objects of sociological analysis.

In this article, in dialogue with other traditions of metaphorical 'border thinking' I argue that one feature of writing which emerges from this actual borderland, a region characterized by extreme interregional mobility, social diversity, and political-economic heterogeneity, has been a rise of distinctive genres that express plural perspectives as a matter of habit. Following on this, I expand on Shahzad Bashir's argument that attention to plural temporalities in 'Islamic' genres helps scholars overcome a nineteenth-century Orientalist problematic of 'universal time' ${ }^{\text {ii }}$ _part of a perspective that leads observers in the 'western' academy to position their work as somehow external to social conditions even as they contextually analyze 'other' societies' texts. Border histories are not necessarily 'resistance' in any sense, but they demand sensitivity to spatial and ontological, as much as chronological, multiplicity. And while they may not be much more 'fundamentally [multi]-perspectivalist' than other Islamic genres are, ${ }^{\mathrm{iii}}$ they are uncommonly democratic in the modern era with respect to the spheres they critically and reflexively engage. But what is the point? What can border histories in general, and from the Afghan-Pakistan borderland in particular, do in global academic life? Like Bashir argues, they can help scholars overcome problematics embedded in coloniality. They can also probably help open academic life to genres that allow more participation by people they represent. But engaging the intellectual interventions possible with border genres requires adopting something of their social commitments too, not just writing about them. So this article is not a call to decolonize history within the frontier, 
This is the accepted version of an article to be published by Taylor and Francis in South Asian History and Culture. Please refer to the published version when citing: http://www.tandfonline.com/loi/rsac20\#.V5Yrj krKUk

Accepted Version downloaded from SOAS Research Online: http://eprints.soas.ac.uk/22691/

which would be unnecessary. It is an invitation to consider multiple relationships among scholars in the world-at-large.

In this article I draw mostly on histories of Khyber-Pakhtunkhwa, or the former North-West Frontier Province, from the early to mid twentieth century—-though my conclusion situates some of these works in the ongoing War on Terror era. The texts I have selected also mostly address Pashto-language social space, although some, as we will see, incorporate other ethnic worlds; and none are concerned with 'Pashtun', or any other, 'identity'. They instead reflect a view of life generally incompatible with an identity-centric reading of history: life as heterogeneous assemblage, a view reflected in the form and content of the histories I consider here.

\section{I: Assemblages, Systems, and Borders}

In this article I assume, inspired mostly by the books I will discuss, that all books are assemblages. Authors interact in networks of actors, ideas, and practices across society, and draw upon and assemble culture into what we read as coherent works, but in reality these works do not cohere without momentum from the other contexts they attach to:

As an assemblage, a book has only itself, in connection with other assemblages.... [T] he only question is which other 'machine' the 'literary machine' can be plugged into, must be plugged into in order to work. ${ }^{\text {iv }}$

Some relevant 'machines' here are universities, and disciplines like history that grew along with historical projects of consolidating nation-states and representing others. They also plug into social networks like policy bodies or professional associations or market-oriented publishers that themselves assemble a variety of social interests. All the above assemble ways of seeing, feeling, and knowing the world that are linked to the basic terms of the conversations, conflicts, and projects they carry, even if they are not 
This is the accepted version of an article to be published by Taylor and Francis in South Asian History and Culture. Please refer to the published version when citing: http://www.tandfonline.com/loi/rsac20\#.V5Yrj krKUk

Accepted Version downloaded from SOAS Research Online: http://eprints.soas.ac.uk/22691/

reducible to those. Authors negotiate all this knowingly and choose which assemblages to link into when they compose something.

In our case, relevant 'machines' also include ones often considered marginal to the modern era: interregional religious traditions; decentralized histories of trade and traffic, devotional publics, and other routes that we (now) think of as crossborder. As we will see, some of these spheres, like religious education or sufi networks, were reorganized to concentrate authority of their own. Others survived fragmentation because they do the opposite: they keep authority distributed and plural, allowing open participation in more eclectic, yet more resilient, networks. I argue that this in itself textures work on the borderland even in dominant academic genres. Further, I argue that 'minor' genres — the present-day tazkira, or biographical dictionary; and Pashto political autobiographies_-better enable such plural imaginations of the world.

In arguing for border historiography, I draw on other traditions of borderland scholarship to help me verbalize what the Pakistani field does intuitively. For instance, intervening in 'border' literature in cultural and postcolonial studies, Tijuana-based poet, critic, and academic Heriberto Yépez asks us to interrogate actual borders between political-economic-juridical systems, and between systems of knowledge and culture, simultaneously and holistically. In his 2007 article 'La frontera como falla' ('Borderland as Faultline’), Yépez advances a view of borderlands as zones of fragmentation, fission, and friction, more than the transgression, hybridity or fusion that he says are often celebrated in cultural and postcolonial studies. ${ }^{v}$ 'Borders' are what we call places where systems reach limits and begin corroding each other into fragments as well as fracturing through their own dynamics, even as constituent fragments productively realign with each other at borders to reshape systems as a whole. To Yépez, borders are illusory, though only partly: they are both cause and effect of spaces where fragmentations, 
This is the accepted version of an article to be published by Taylor and Francis in South Asian History and Culture. Please refer to the published version when citing: http://www.tandfonline.com/loi/rsac20\#.V5Yrj krKUk

Accepted Version downloaded from SOAS Research Online: http://eprints.soas.ac.uk/22691/

rather than concentration, reach a peak. Of course, Yépez notes, the idea of 'system' presumes an illusion of self-contained coherence that networks only begin to project when they enforce hierarchy, authority, exclusion. He therefore prefers to think of ‘pseudo-systems’ while maintaining a provisional shorthand of ‘system', as I do here. And he notes that 'systems of knowledge', like the political-economic networks they are attached to, rely on more than one mode of assembly. A question for any given work is how it helps some systems assimilate fragments of others. Does it force them to break other ties, and subordinate them to dominant ways of seeing?

In our region: as state power expands, do individual borderland brokers take on repertoires of cultural power that mirror colonial governance or Persianate kingship in microcosm, creating hierarchized social fragments? Or do ad hoc state negotiations with borderland brokers create entirely new techniques of power, ones that remain unequal but that reshape power across the state system? Does an 'academic' history drawing on English or Urdu archives of frontier knowledge, archives organic with the exercise of imperial rule in the frontier, assimilate knowledge generated by other worlds—say, possession by fairy-spirits, or anonymous saint-poetry—as evidence to its arguments, arguments that position themselves on the same universal scale as empire projected itself? Conversely, can we find examples where such fragments build a text’s assumptions of how the world works, overwhelming and subordinating 'history' to some alternate universality? Or, in contrast to all the above, might authors be comfortable negotiating plural ways of knowing, inseparable from plural ways of acting effectively... and as a result, stage their texts as interplays of knowledge systems alongside the interplay of the social networks that they are part of?

Both these modes of assembly_hierarchic, systematizing 'filiation', and lateral, rhizome-building 'alliance’—are present throughout the assemblage I call ‘border 
This is the accepted version of an article to be published by Taylor and Francis in South Asian History and Culture. Please refer to the published version when citing: http://www.tandfonline.com/loi/rsac20\#.V5Yrj krKUk

Accepted Version downloaded from SOAS Research Online: http://eprints.soas.ac.uk/22691/

history’. But I argue that a tendency to dismantle rigid patterns while tactically drawing on their elements is one of border historiography’s strengths....and border society’s.

Throughout this article, I turn to the historiographical life of one border actor, Haji Sahib of Turangzai, repeatedly as an illustrative example. I begin the next section by discussing the wider conversations into which one work on Haji Sahib is, directly or indirectly, 'plugged'. I focus on interplays within heterogeneous border networks—of actors, but also of genres of knowledge and action. While many historical works about the region express themselves in universalizing languages of History, traces of multiplicity structure their narratives and live on in their bibliographies, as we will see.

\section{The 'Multidimensional' Haji Sahib}

In 2015 the National Institute of Cultural and Historical Research in Islamabad published the latest in a series of books on the borderland: Reforming the Pakhtuns and Resisting the British. Its author, Altaf Qadir (Department of History, University of Peshawar) had earlier addressed the career of Sayyid Ahmad of Rai Bareilly (17861831) and argued that the Sayyid's anti-imperial borderland insurgency failed because he and his followers, transplants from the north Indian plain, had failed to integrate their activism sufficiently to frontier forms of life. ${ }^{\text {vi }}$ Reforming the Pakhtuns focused on a more recent activist, Haji Sahib of Turangzai (1858-1937), who became one of the frontier's most important activists in the early twentieth century precisely because, Qadir argues, he was more successful than Sayyid Ahmad in integrating tactics simultaneously to crossborder upland worlds and the colonial heartland of Peshawar Valley. A border-crosser in many senses, Haji Sahib must arise in passing in all histories of the late colonial frontier. But despite his importance, Qadir's is the first monograph 
This is the accepted version of an article to be published by Taylor and Francis in South Asian History and Culture. Please refer to the published version when citing: http://www.tandfonline.com/loi/rsac20\#.V5Yrj krKUk

Accepted Version downloaded from SOAS Research Online: http://eprints.soas.ac.uk/22691/

devoted to him in English, though much has been said in Pashto. A saint as well as an activist, major folk-poetic works are devoted to him too: devoted in the religious sense.

In its scope, Altaf Qadir explicitly positions Reforming the Pakhtuns and Resisting the British in dialog with standard works including Sayed Wiqar Ali Shah's Ethnicity, Islam and Nationalism; but Qadir contrasts his work with ‘sociopolitical histories' by describing his focus to be the 'multidimensionality’ of Haji Sahib’s activist life-an emphasis that recurs, if less explicitly, in the work of others at University of Peshawar such as Abdul Rauf. ${ }^{\text {vii }}$ With this notion, Qadir points to how Haji Sahib’s actions were varied in a frontier region that was far from homogeneous in the way it was colonized, and were aimed at subjectivity as well as institutions. Qadir does not address a wider literature on decoloniality, but both his book and its subject view decolonization as a matter of breaking colonized ways of thinking and acting, of reinforcing yet transforming extracolonial forms of life, and of projecting local activism onto other social scales. Haji Sahib’s strategy was to retain local ownership over action while linking to wider struggles in modes like pan-Islam, Gandhianism, and socialism.

Qadir's narrative trajectory is suited to this argument. He begins by describing how the extension of imperial rule fragmented and localized frontier life by creating administrative borders, corresponding to varying hierarchies in differently-administered regions. Some policies created 'tribal' institutions among populations in regions directly adjacent to Afghanistan, while others reinforced landowning elites as well as extensive bureaucratic and legal regimes in the Peshawar Valley and areas adjacent to Punjab. Finally, an overarching securitization affected all areas of the colonial frontier in various ways. Against this backdrop, Qadir describes Haji Sahib’s social reforms, which built on his devotional practice but which reclaimed practices like jirga (ad hoc council) or lashkar (militia), to effect wider transformations. These ranged from pre-1915 boycotts 
This is the accepted version of an article to be published by Taylor and Francis in South Asian History and Culture. Please refer to the published version when citing: http://www.tandfonline.com/loi/rsac20\#.V5Yrj krKUk

Accepted Version downloaded from SOAS Research Online: http://eprints.soas.ac.uk/22691/

of colonial local councils and monetary stipends, to creating a web of independent schools, to tribal area insurgency. All built on less hierarchic, more flexible and openended reformulations of colonized traditions such as tribal councils, or local hierarchies like sufi allegiance networks. Finally, other historians describe how the independent schools grafted religious curricula to modern institutional techniques while opening the door to indigenous knowledge and to emphases from the wider Indian nationalist movement; this eclecticism was integrated into the curriculum of the second generation of schools inspired by Haji Sahib, those built by 'Abdul Ghaffar Khan and the Congress-allied Khudai Khidmatgar movement, in 1921. ${ }^{\text {viii }}$

From there, we read in Chapter Three about Haji Sahib’s political reform, which primarily aimed at boycotts of British institutions and the hierarchies of land, law, subsidies, and tax that formed their local interface. This chapter especially highlights variable ways that Haji Sahib targeted his reforms to deterritorialize different manifestations of imperial rule in the Settled Districts, the Tribal Areas, and the Princely States and Khanates. Chapter Four moves on to discuss how these networks coalesced into militancy, in part through emergent techniques of sufi organization and 'ulama networks described in Chapter Three. The final chapter describes links to other horizons of anticolonial activity in the First World War era and after, such as the all-India and transnational networks of Mahmud al-Hasan 'Shaykh al-Hind'. All these run parallel in time, giving a pluricentric effect: actors and institutions that appear incidentally in some passages recur and receive greater focus in subsequent chapters.

Qadir's work, a revision of his 2004 M.Phil work, is shorter and more restricted than others that address similar trans-frontier subject matter. The best example is Sana Haroon’s 2007 Frontier of Faith, which devotes some attention to Haji Sahib amid a narrative of political sufi networks in the borderland. In contrast to most histories of the 
This is the accepted version of an article to be published by Taylor and Francis in South Asian History and Culture. Please refer to the published version when citing: http://www.tandfonline.com/loi/rsac20\#.V5Yrj krKUk

Accepted Version downloaded from SOAS Research Online: http://eprints.soas.ac.uk/22691/

frontier in the late colonial period, Qadir and Haroon rely on the colonial archive but both also draw heavily from history production beyond what Trouillot calls 'the guild'. ${ }^{\text {ix }}$ To explore the range of this literature, consider Qadir's bibliography. It includes Urdu histories produced at the revivalist Deoband seminary about its own graduates, including Haji Sahib, that sit parallel to the western academic tradition as equally exclusive counter-authority in South Asia and beyond. These histories bear traces of millenarianism, but sanitized of the full devotional ontology that drove ecstatic insurgency; and they also illustrate a commitment to facticity that underpinned Deoband's reformism, with its roots in disputations over positive law. But both Qadir and especially Haroon also rely on significant amounts of oral history work, attesting to the fact that the centralized field of professional history in Pakistan has often failed to incorporate basic elements of common memory in the borderland, as elsewhere. Qadir cites prose narrative in Urdu and Pashto, like $\bar{A} z \bar{a} d \bar{\imath} k \bar{\imath}$ Talāsh by Miān Akbar Shāh and Da Azzādī Jang by poet 'Abd al-Khāliq Khalīq, among other works by autodidacts who collated the 'common-sense' emergent in local conversation about the past into nowdefinitive accounts. Qadir and Haroon both draw heavily on well-known tazkiras, or biographical dictionaries, some containing primary material by the subjects themselves. Finally, Qadir draws on unique Pashto sources like Nur Muhammad's versified Pashto account, Mujāhid-i Sarhad, which evokes wider parts of the Pashto literary formation including its vital tradition of chapbook histories and performed verse narration. ${ }^{\mathrm{x}}$

I discuss critical examples of some of these genres below, in an exploration of scholarly genres that might be more intuitive to the people they represent, and more intuitively adapted to depict what I focus on in the next section: a fragmented character of borderland history. But first, how do these networks of intertextuality play out in academic histories? Both Haroon's and Qadir's works are much more intimately aware 
This is the accepted version of an article to be published by Taylor and Francis in South Asian History and Culture. Please refer to the published version when citing: http://www.tandfonline.com/loi/rsac20\#.V5Yrj krKUk

Accepted Version downloaded from SOAS Research Online: http://eprints.soas.ac.uk/22691/

of local knowledge than most Anglophone histories of the frontier are; and both process it into narrative prose. Haroon is more explicit on this, and argues a need to transcend what she sees as tendentious narratives like, for example, the spiritual family trees establishing 'authenticity' and authority that she discerns as the key concern of the 'highly intellectualized and rationalized tazkira form'. xi

I offer a slightly different view on tazkira history later, but Haroon is certainly right that the actors in her account including Haji Sahib exceed any single narrative core, and her account grants far more indeterminacy and contingency to history than most narrative histories of the frontier have. But Haji Sahib and similar actors do not sit well in any one ontological perspective either. Indeed, his activism was premised upon a dexterity in perceiving, inhabiting, transforming, and interlinking plural ontologies. Both works disassemble other modes of knowledge and repackage their contents as information but Qadir's is distinctive even as its base of sources is narrower. First, unlike Haroon's it does not fully succeed as positivist history because it is less skeptical of its sources' truth-claims. Second, 'multidimensionality' is built directly into the central claims of the work, as is a deliberate incommensurability between knowledge produced by Haji Sahib’s evolving activism on one side, and the realm of the colonial on the other. Along with that, if we read charitably, is an understanding of this activism as a principle of opening up extra-imperial space, rather than an understanding that converts it into an account of competing sources of authority or authenticity. This is so even if the work betrays those claims in its narrative commitment to a single ontological perspective, in a genre like positivist history that is itself historically organic with selftranscendentalizing authority like that of the nation-state or of empire.

\section{III: Multiplicity and Fragment-History}


This is the accepted version of an article to be published by Taylor and Francis in South Asian History and Culture. Please refer to the published version when citing: http://www.tandfonline.com/loi/rsac20\#.V5Yrj krKUk

Accepted Version downloaded from SOAS Research Online: http://eprints.soas.ac.uk/22691/

Throughout the rest of this article I want to discuss work that addresses fragmentation and multiplicity on either the meta-analytic level, placing this as the central object of narration, or on the structural level. The most explicit arguments of this point are found in Ben Hopkins and Magnus Marsden’s Fragments of the Afghan Frontier, and I will discuss that work before moving on to works that integrate multiplicity into their structure: two tazkiras and two autobiographies.

Fragments of the Afghan Frontier goes well beyond Qadir's work in making multiplicity central to its claims. Hopkins’ historical portions draw on British archival sources and are perhaps the fullest sustained discussion of piecemeal and unpredictable imperial management processes through which the frontier came to be fragmented: into zones where rigidified 'tribal' custom and elders ruled, and zones where other modes of colonial power operated. He also notes how largely improvised borderland practices were soon generalized to reshape policy elsewhere. Policies that govern the Tribal Areas, for instance, appear to be modifications of ones first developed in negotiations with Baloch elites elsewhere on the empire's Afghan border. A similar dialectic was true of non-colonial agency as described in a chapter on the aforementioned Sayyid Ahmad's interregional mujahidin network; colonial responses to its outposts in the tribal areas; and responses to 'religious fanatics' elsewhere. This chapter also demonstrates how non-imperial actors’ own interregional networks also reproduced local fragmentation. Following on this, and complementing Hopkins' top-down vantage point, Marsden's ethnographic work traces decentralized experience across zones of mobility beyond the Pashto-sphere that fluctuate unpredictably amid geopolitical change. This includes physical mobility but also brings in discussion of culturescapes as, for instance, Chitrali ecosystems intersect with Afghan lives globalized by decades of war. The following relates to Chitrali youth but ties that discussion to larger arguments: the book seeks to 
This is the accepted version of an article to be published by Taylor and Francis in South Asian History and Culture. Please refer to the published version when citing: http://www.tandfonline.com/loi/rsac20\#.V5Yrj krKUk

Accepted Version downloaded from SOAS Research Online: http://eprints.soas.ac.uk/22691/

fragment both postcolonial and local-nationalist constructions of the borderland that are phrased in terms of religious militancy and Pashtun ethnicity, in favour of a view of decentralized multiplicity. Recalling Haji Sahib’s multidimensionality, this seems relevant to the frontier at large:

[People] in the region understand their world in relationship to a multiplicity of sometimes discrete and at other times negotiable and interactive modes of morality, sociability, cultural influence, political dynamics, and religious ideologies and concepts. ${ }^{\text {xii }}$

In sum the book self-reflexively avoids unified narration to build a series of accounts of interwoven social fragments, which are fragments in part due to the way they are responsive to ties beyond any local horizon. Still, the two halves' most recurrent themes diverge: domination of transregional space from the top as seen in an imperial archive; versus everyday lives, lived in transregional space in the contemporary world, as seen by an ethnographer. State domination of space; entrepreneurial circulation across decentralized landscapes: each section incorporates some of the other theme. Each also addresses middle spaces, virtual and material, that do not sit easily in this typology, and the more contemporary sections of Fragments point out how entrepreneurial circulation also opens up local inequalities, conflicts, contradictions. But divergent emphases are apparent in the relative richness that each theme receives, and this might give an impression that each era was characterized mostly by these respective themes.

Related but separate, a relative polarity in the topics of narration relates to a parallel polarity in sources and epistemologies: the surveillatory colonial archive versus the decentralized ethnography of everyday life in social networks today. In the process of building the accounts, the scholarly 'machine' behind the analysis authorizes the account to project its own universality and survey the external world. But in life, 
This is the accepted version of an article to be published by Taylor and Francis in South Asian History and Culture. Please refer to the published version when citing: http://www.tandfonline.com/loi/rsac20\#.V5Yrj krKUk

Accepted Version downloaded from SOAS Research Online: http://eprints.soas.ac.uk/22691/

standing in between these poles and tracing the macro-textures of the frontier while maintaining the autonomy of fragments, are those exact multi-perspective networks of knowledge—pluriversal ones, to use Enrique Dussel’s term—-that Qadir’s and Haroon’s bibliographies trace, that Fragments too may not inhabit but that it does point to. ${ }^{\text {xiii }}$ Marsden discusses structures of feeling tied to Persianate literary traditions, and how everyday participation in them disrupts binaries of urban and rural, elite and otherwise. He also notes the educational systems to which most of his trader interlocutors send their sons, the ones in which they themselves were often educated too. And most of Qadir's and Haroon's local texts plug into these same networks. But one thing is less visible here than in the latter accounts: works emergent in these and other knowledge systems, in the ground between everyday border life and interregional culturescapes and the state, are acutely sensitive to, and contest, a range of persistent macro-scale inequalities and patterns of conflict.

One wonders if the account's fragmentation might outstrip the fragmentation of borderland space in real life. That space does have a macro texture. Do not spatialized inequalities, forged on the level of global and national-scale politics, still exercise overwhelming effects on local life now as they did in the colonial era, even if actors do forge their own destiny in extra-imperial interregional space? In a word, is coloniality not a texture of this world? When we look at modern instantiations of Persianate genres in our area, which we soon will, we will see that many are socially-invested interventions in that which they represent. In a sense, the accounts of the extreme multiplicity of life in networks, in the ethnographic parts of Fragments of the Afghan Frontier, surpass the dialectic of coloniality and resistance. Focusing on entrepreneurial or otherwise mobile agency rather than dispossession mirrors much of the reality in which many of its ethnographic subjects craft their lives. Note that this was Haji Sahib’s 
This is the accepted version of an article to be published by Taylor and Francis in South Asian History and Culture. Please refer to the published version when citing: http://www.tandfonline.com/loi/rsac20\#.V5Yrj krKUk

Accepted Version downloaded from SOAS Research Online: http://eprints.soas.ac.uk/22691/

initial aim: to make empire not impotent, but irrelevant. On the other hand, as a book

Fragments plugs these actually-existing fragments into its scholarly 'machines' when it makes them legible, and detaches them from frontier knowledge-machines of which they are constitutive parts. This includes legacies of consciously defending autonomy that mark many educational and cultural networks in the border region, including ones that are directly and indirectly related to traders’ educational networks. It is a specific incompleteness not to consider coloniality in the present, just as it is counterproductive to essentialize frontier history as mostly resistance and evasion, overlooking entrepreneurial agency as well as more local forms of domination; and just as it would be counterproductive either to subordinate some domains of frontier life to others in linear narration, or to build a completely fragmented account.

Fragments is hardly alone in cleaving off contentious entanglement in the nearpresent. A depoliticization involving some global entanglements in accounts related to one of the most geopolitically sensitive regions in the world is a feature of Anglophone academic life. Whatever the reasons, and factors are numerous, this is enabled by the way that, as Walter Mignolo contends, even multiperspective works in the western academy in practice accept the existence of a 'pluriverse' 'out there’ while observing that pluriverse and its entanglements from a position that is seemingly transcendent, disengaged from it. ${ }^{\text {xiv }}$ Such knowledge systems by nature fragment other systems and assimilate their knowledge to themselves. But what would it take to do the opposite, to deliberately plug Anglophone scholarly work into border networks? Is it enough to write for wider audiences, and if so, how? Adjust to topics of widespread concern in the borderland itself? Ethnography often already does that. Would one have to adjust one's genre, then, or maybe one’s social commitments? Work in the global south, of course, and especially border history, has long negotiated all the tensions arising here. In the 
This is the accepted version of an article to be published by Taylor and Francis in South Asian History and Culture. Please refer to the published version when citing: http://www.tandfonline.com/loi/rsac20\#.V5Yrj krKUk

Accepted Version downloaded from SOAS Research Online: http://eprints.soas.ac.uk/22691/

remainder of this article, I describe two modes of 'fragment' histories that illustrate this.

\section{IV: Tazkira as border history}

First is the tazkira, a biographical dictionary, and reading the genre as critical social representation is not a new idea. Usually a series of entries about individual men of influence, it is often possible to trace social networks in tazkiras as most entries mention other people too. Hermansen and Lawrence argue that the genre in South Asia is one of ‘memorative communication’: specifically, a way to illustrate spatialized networks of urbane Muslim culture in Hindustan. Over time, emphases in tazkiras of poets shifted from depicting the personal networks of a markaz (centre) and its ustad (master); to highlighting distinct regional cultural scenes, amid localized princely patronage in the eighteenth century; to building coherent schools or canons, under the influence of colonial spatiality and western understandings of literary culture. Meanwhile a Mughalera tazkira of sufis, sponsored by the court, will illustrate very different networks than one by, say, a renegade intellectual like Badauni. Hermansen and Lawrence argue that in reading tazkiras, then, the key is to connect them to "the places and contexts...that generated the need for memorative communication at the heart of tazkira writing." ${ }^{\mathrm{xv}}$

Does this reading strategy again place a positivist observer at a transcendent point above the tazkira? That assumes tazkira composers are not conscious of their own act of social creation involved in the networked analysis they build. That is implausible in the premodern cases and untenable for modern tazkiras. Many reflexively incorporate their own patronage contexts and undermine them at the same time. And, the form allows sufficient nuance that some historians choose it in an age when they might also adopt modern prose narration. Let me elaborate on all this at length. 
This is the accepted version of an article to be published by Taylor and Francis in South Asian History and Culture. Please refer to the published version when citing: http://www.tandfonline.com/loi/rsac20\#.V5Yrj krKUk

Accepted Version downloaded from SOAS Research Online: http://eprints.soas.ac.uk/22691/

As Hermansen and Lawrence argue, the tazkira can be an elitist endeavour: representing cross-temporal and cross-regional lineage power; mapping individuals into patronage hierarchies. On one level, the history of writing tazkiras in twentieth-century Afghanistan seems to uphold this reading. Leading up to 1928, the Afghan monarchy had kept good ties with deterritorial border networks including those of Haji Sahib. But following on a series of borderland uprisings, a civil war in 1928 led aspiring monarch Nadir Khan to negotiate with borderland brokers and incorporate their networks into state rule as a way to subordinate them. By 1931 the monarchy brought large nomadtrading tribes and sufi and ulama networks into its fold. It hierarchized them by giving elders limited influence in central bodies reporting to the state, and it purged competing networks with extreme prejudice. The Interior Ministry, in league with tribal elites in Qandahar, did the same with critical borderland intellectuals, many of whom had been active in face-to-face and print networks that eventually linked into to the anticolonial movement via Haji Sahib. After 1930 these intellectuals and others received repeated and insistent invitations by the Ministry, and even the king directly, to join the central Literary Society. To an extent, borderland intellectuals helped convert insurgent Pashto knowledge from their networks into territorialized knowledge instead as they rose through state publication circles.

In short, the post-1930 monarchy ruled by incorporating and subordinating borderland 'fragments', and state intellectual production mirrored this. Prior to 1928, dominant social representations at the court reflected a centre-outward view, in the prose of international Persian modernism. ${ }^{\text {xvi }}$ But in subsequent decades, a networked imagination, in more traditional genres that were accessible to wider publics, reigned supreme. As the Literary Society morphed into the Pashto Academy under the direction of 'Abd al-Hayy Habibi, it produced increasingly elaborate tazkiras that outlined a 
This is the accepted version of an article to be published by Taylor and Francis in South Asian History and Culture. Please refer to the published version when citing: http://www.tandfonline.com/loi/rsac20\#.V5Yrj krKUk

Accepted Version downloaded from SOAS Research Online: http://eprints.soas.ac.uk/22691/

progression of Pashtun tribes and saints from illustrious ancestors, in the process of building a Pashto canon. Unruly fragments were slotted into family trees in poetic tazkiras like Habibi's Paxtāna Shu 'arā (1941). And when that map also proved too sparse, Habibi produced a manuscript called Pața Khazāna (1945) that reoriented early Pashto literary culture not toward radically antiterritorial mountain sufism, as had been the existing picture, but to a fictive premodern tribal chieftain-poet, 'Amir Kror' .

At the same time, tazkiras produced in this and subsequent eras negotiate multiple systems of knowledge and power. Quite in contrast to a view that they establish 'authenticity', some at once reflexively highlight the webs of patronage from which they emerge, and enable readers to construct many other networks too. In fact, I constructed the genealogy above, and a very different one in the next paragraph below, both from Abdul Rauf Benawa’s 1961 Osanī Līkwāl (Modern Writers). This threevolume tazkira juxtaposes people like Interior Minister Muhammad Gul Mohmand, chief promoter of an elite patriarchal mode of Pashtun nationalism and the creator of the Pashto Academy, with others like Sayyid Hasan who died while imprisoned for his socialist stance, or Siddiqullah Rixtin, whose life highlights sufi links to Haji Sahib of Turangzai and to Kabul alike. Some entries are especially rich. Benawa invited subjects to submit their own narratives, and his colleague Qiyam al-Din Khadim chose to sketch the networks of people and texts that composed him: village life; a decentralized ustadbased education in linguistics, literature, and Neoplatonic philosophy in sites from the Kunar mountains to the colonial metropolis of Delhi; small-town life as a schoolteacher in Khyber; embryonic socially-activist discourse from the NWFP’s decolonization struggle; and pan-Islamic philosophy in Urdu and Persian by Muhammad Iqbal. xvii $^{\text {}}$ What emerges from this tazkira? The Minister Muhammad Gul Mohmand’s entry helps readers see hierarchizing processes of elite culture and socioeconomic 
This is the accepted version of an article to be published by Taylor and Francis in South Asian History and Culture. Please refer to the published version when citing: http://www.tandfonline.com/loi/rsac20\#.V5Yrj krKUk

Accepted Version downloaded from SOAS Research Online: http://eprints.soas.ac.uk/22691/

power, including the gradual formation of the Pashto Academy that produced this

tazkira. Meanwhile Khadim’s entry links to Mohmand’s, but also provides numerous reference points that link to other less-detailed entries across the tazkira. It helps show how individuals like Khadim and Rixtin were vital in active in building cross-border antiauthoritarian networks in daily life, and through Persian, Pashto and Urdu print and oral culture. Many other points of linkage are found in the tazkira's longest entry, that of Ajmal Khattak of Nowshera, British India: a Pashtun nationalist poet, and backbone of the pro-regionalist left in post-independence Pakistan, as well as an activist in the anticolonial movement. His entry opens into the networks that sustained those political movements. Finally, these networks are apparent, but another hidden presence across the tazkira, available to initiated contemporaries and present-day retrospective observers, is the underground pro-democracy network, the Wex Zalmiyan: an important influence on print and oral culture alike, and of which Khadim and this tazkira's composer, Benawa, were founding members.

In short, tazkiras and their networked imagination were 'memorative communication' that underscored an elite, broker-centred imagination on behalf of the monarchy, but they also arrange information in a way less violent to the plural perspectives of their constituent elements than linear prose might be, and they allow for an antiteleological view of fragmented border networks that still incorporate inequality and concentrations of power. Indeed, as I discuss elsewhere, later tazkiras highlighted other convergences and diffusions of fragments, as well as their frictions and conflicts: the gendered affective life of honour in local landowner-tenant relations in Shewa, or the Pashto poetics of cross-border Sikh commercial networks. ${ }^{\text {xiii }}$

Finally, tazkiras narrate explicitly, but also with suggestive gestures. This means 
This is the accepted version of an article to be published by Taylor and Francis in South Asian History and Culture. Please refer to the published version when citing: http://www.tandfonline.com/loi/rsac20\#.V5Yrj krKUk

Accepted Version downloaded from SOAS Research Online: http://eprints.soas.ac.uk/22691/

a tazkira can open doors to some networks and close others depending on the reader.

Benawa's work bars entry to some organized networks, like remnants of the Wex

Zalmiyan, to anyone not already initiated and holding key knowledge: protecting them, to an extent. But also, this same gestural factor allows nuance in depicting a range of loose and strong ties. The Zalmiyan relied on a cadre of activists but built its following partly by engaging unaffiliated intellectuals who sang oral poetry or delivered Friday sermons, as part of a late 1940s campaign to promote what we might now call intersectional class, tribal, ethnic, religious, and gender equality across rural Afghanistan. Some years ago I asked one of their surviving activists about this. Himself an 'alim trained by border intellectuals like Khadim, as well as a poet and a prolific tazkira-writing literary historian, ‘Abdullah Bakhtani said I might go too far to think in terms of communications structures even though the activism was deliberate. Existing tazkiras evoked the full range of connectedness better than my prose, in a subsequent article about it, managed to do. If I think honestly, Bakhtani told me this at the time. 


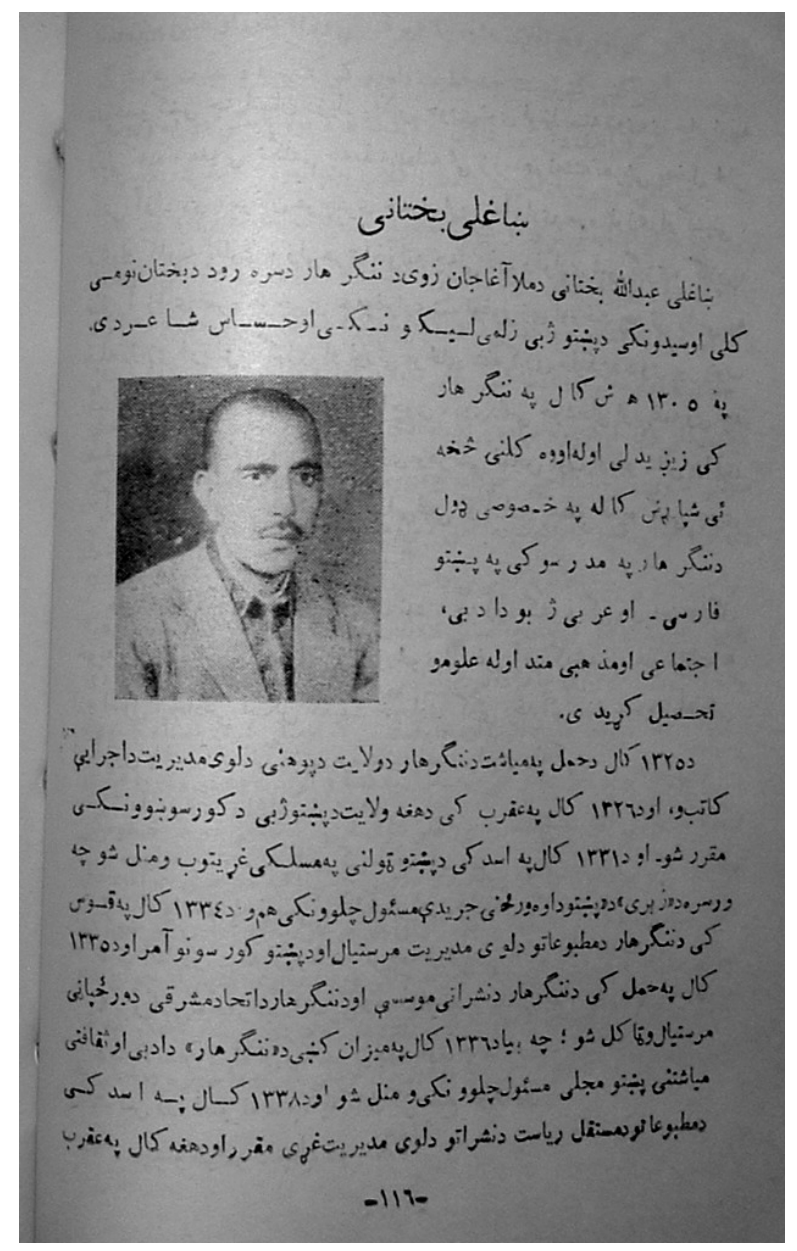

Figure 1. From Osani Likwal, a tazkira entry about a tazkira author: a very young 'Abdullah Bakhtani.

So part of my thinking about genre was shaped by the realization, remarkable only in its banality, that of course activists who simultaneously engage, evade, and contest power on multiple fronts would create genres that mirror the contours of their activities. But another factor was undergraduate teaching, and my dissatisfaction with a lack of readings in English on major aspects of post-independence frontier history. I eventually provided selections from Celebrities of NWFP: an English-language tazkira organized by Professor Fazal Rahim Marwat, who solicited research-based entries from scholars across the province, and published it through Peshawar University in 2005. ${ }^{\mathrm{xix}}$ This book invites readers to construct a history of NWFP actively, by exploring networks that arise in the text. It presents knowledge in widely varying forms without 
This is the accepted version of an article to be published by Taylor and Francis in South Asian History and Culture. Please refer to the published version when citing: http://www.tandfonline.com/loi/rsac20\#.V5Yrj krKUk

Accepted Version downloaded from SOAS Research Online: http://eprints.soas.ac.uk/22691/

undermining any, even exceeding most Pashto-language tazkiras in this regard. Take the entry on Haji Sahib of Turangzai, by Syed Iftikhar Hussain. Beginning with a Persian couplet and an idiosyncratically-digested citation of Hegel, the introduction situates Haji Sahib between a transgenerational space of collective emotion, and the contingent realm of agency. It shifts to a description of Haji Sahib’s early educational life, forged by transnational mobility similar, in its own era, to that in Marsden's account. It then discusses Haji Sahib’s eventual sufi networks before moving into a biography inflected by hagiographic accounts. Across some too-brief emotive paragraphs, it traces his forays as a house thief and, briefly, as a hired gun, and his subsequent conversion through supernatural intervention to socio-religious service. In passages relating to Haji Sahib’s school network, Hussain weighs sources against each other like any positivist historian. Then much of the rest of the entry is eclectic biography. It describes social engagement with local life through the langar (a saint's community kitchen and site of redistribution) and the lashkar (ad hoc militia). It highlights Haji Sahib’s connections to transregional pan-Islamic activism and elite Afghan politics, before chronicling Haji Sahib’s insurgency. It finishes with elegy-songs by Haji Sahib’s sufi devotees, and by 'Abd al-Khaliq Khaliq, the leading popular poet of the Congress-allied civil disobedience movement, the Khudai Khidmatgars. Delivered without comment, the poetic selections are not evidence in an argument. Rather, they frame the terms of discussion: an explication of Haji Sahib’s multidimensional and interregional networks, and their affective, trans-individual and trans-generational nature. It is an argument-bydemonstration that fits into the tazkira fractally, as Haji Sahib’s and the Khudai Khidmatgars’ networks both unfold throughout the rest of the book too.

Leading in different directions is the entry on Maulana Mufti Mehmood, by Fazlur Rahman. I include this entry to show how the tazkira can engulf nation-state 
This is the accepted version of an article to be published by Taylor and Francis in South Asian History and Culture. Please refer to the published version when citing: http://www.tandfonline.com/loi/rsac20\#.V5Yrj krKUk

Accepted Version downloaded from SOAS Research Online: http://eprints.soas.ac.uk/22691/

history too, or how points of connections in tazkiras can lead outward into other forms of history-writing, or both. The narrative begins with a view of its protagonist's lineages in Afghan nomad trading tribes and sufi educational lineages in the Gomal, then moves into his life in the education systems of north India: Rohilla networks to Moradabad and elsewhere in Rohilkhand still brought borderland scholars to India, including Mehmood and his teachers alike. From there we read how Mehmood's career progressed, as he returned to NWFP and built solidarity networks in the early 1950s to south Punjab by rising to prominence through debates in his professional field, jurisprudence. This networking eventually enabled him to consolidate all Deobandi madrasas in Pakistan under an umbrella organization, the now-famous Wafāq al-Madāris.

But was it legal debates alone that enabled this? The narrative then rewinds back to the colonial period, to describe Mehmood's interaction in pre- and post-independence Deobandi politics. He worked as a provincial political worker under Deobandi leaders Mufti Kifayatullah and Maulana Hussain Ahmad Madani during the foundation of the Jami'at 'Ulama-i Hind (JUH), a lobbying group of Deobandi scholars. The skills he gained in this and in the Khilafat Movement helped him organize, amid the 1953 antiAhmadi agitation in Punjab, a kind of social action different to any in this article so far: a mobilized public. From here the narrative incorporates traditional Pakistani politicalhistorical narration, as Mehmood changes the JUH into a formal political party, the Jami`at 'Ulama-i Islami (JUI). We read of his adaptation to opposition socialist parties on Pakistan's pan-periphery: an alliance with the National Awami Party, which in the NWFP drew on remnants of the Khudai Khidmatgars. But the narration also suggests he was installed as NWFP Chief Minister in 1972, when JUI sat in coalition with the NAP in opposition to the Pakistan People’s Party (PPP) in Islamabad, as a broker between frontier networks and Bhutto at the centre. The JUI was hardly relevant in electoral 
This is the accepted version of an article to be published by Taylor and Francis in South Asian History and Culture. Please refer to the published version when citing: http://www.tandfonline.com/loi/rsac20\#.V5Yrj krKUk

Accepted Version downloaded from SOAS Research Online: http://eprints.soas.ac.uk/22691/

terms, but Mehmood's madrasa networks already exercised a brokerage role between elites and the street in multiple regions. He was just as border-crossing as Haji Sahib was earlier, and his entry is an important node. Contextualized within the full tazkira, it highlights how 1972 was a watershed moment when centre-frontier relations in the Pakistan federation undermined NWFP’s traditionally socialist Deobandi tendency, allied as it was with Pashtun nationalist rhetoric that the anti-ethnic centrist state found alarming in the wake of Bangladesh's secession. Activism by Mehmood and his colleagues fragmented frontier worlds in new ways, colonizing them with new public religious culture and reorienting them toward Islamabad to a greater extent than before. Mehmood’s entry looks at first like disjointed chronological narration because, like tazkiras are, it is really organized to facilitate interplays of diverse sociospatial and temporal domains. In the context of this tazkira, it alerts us to processes of respatialization. Mehmood was ultimately most influential through informal power, which drew on Deobandi social techniques gained not only from frontier life but from north Indian mass reformism too. As Sumit Guha argues in 'The Politics of Identity and Enumeration', an idea of elites as the significant agents in a community shifted in early twentieth century British India to a more homogenized idea of 'the masses', due to political changes in the colonial structure. ${ }^{\mathrm{xx}}$ That change did not initially touch the border landscape fragmented between Afghanistan, the Tribal Areas, and landowner society of the Settled Districts, to which Haji Sahib of Turangzai adapted. But the anticolonial movement of the 1930s produced some massifying effects, while by Mehmood's 1970s, civil society and patronage networks alike in the Settled Districts were hollowed out by decades of Cold War-era US-supported authoritarian rule that viewed even their soft leftism with suspicion. Any remnants of the Khudai Khidmatgars' cross-class networks were brittle, and newer populist modes of mass 
This is the accepted version of an article to be published by Taylor and Francis in South Asian History and Culture. Please refer to the published version when citing: http://www.tandfonline.com/loi/rsac20\#.V5Yrj krKUk

Accepted Version downloaded from SOAS Research Online: http://eprints.soas.ac.uk/22691/

connectivity helped Mehmood tie older fragments of the frontier to hierarchies beyond the province as he shifted between new 'central' and 'frontier' worlds.

In short, in contrast to an idea that tazkiras are a form that constructs exclusive authority or authenticity, the tazkiras here stage ongoing relationships between state power, crossregional entrepreneurship of borderland brokers, and life in border localities. They keep readers' eyes on both poles of political economy present in Fragments of the Afghan Frontier and also on ground in between. Their decentralized view complicates coherences of centre and margin, while also reflecting large-scale textures of inequality, highlighting how even in times and places when borders are porous and interregional flows are extreme, centres of colonial gravity persist. This anticipates empirical work in political economy. As Alia Qaim demonstrates, frontier brokers capitalize on borderland positionality but reinvest capital, clienthood, and more, into concentrated hierarchic networks of ‘centres'—provincial, national, or global. These patterns in turn help continuously re-fragment the frontier by pulling various segments of it in differing transregional directions — that is, they re-frontierize it—and they exacerbate local and interregional contradictions and inequalities in the process. ${ }^{\mathrm{xxi}}$ Mehmood did the same in cultural spheres.

Of course the above is just one possible map through these works. Modern tazkiras, at least, are open enough that one might construct any number of others. But this can be true of narrative as well, particularly in what Deleuze and Guattari call, referencing Kafka, 'minor literature’: messy narratives told from marginal vantage points that give readers no 'proper sense or figurative sense, but only a distribution of states';xxii ones that give readers a multiplicity of connections and let them forge paths meaningful to them, rather than leading readers toward fixed linear goals determined by overarching authority. What distinguishes tazkiras from 'minor' narrative, and 
This is the accepted version of an article to be published by Taylor and Francis in South Asian History and Culture. Please refer to the published version when citing: http://www.tandfonline.com/loi/rsac20\#.V5Yrj krKUk

Accepted Version downloaded from SOAS Research Online: http://eprints.soas.ac.uk/22691/

distinguishes the form in general, is an archival impulse. Tazkiras can be infinitely

expanded, as another tazkira by Benawa, Da Afghanistan Numiyali, illustrates. Benawa started alphabetically with the first letter in Pashto, incorporating names from all walks of life, in all periods. He stopped near the end of his life at four volumes and over two thousand pages, including appendices that backtracked in the alphabet to add names he had missed earlier. He had only gotten through the second letter.

\section{V: Individual Life as Assemblage}

Of course, however large a tazkira is, its networked potentiality cannot replicate that of the world at large. The selective act of tazkira assembly still defines landscapes in space and time that its compilers wish to highlight, even if it is designed to remain open to radically unpredictable maps too. And in practice, tazkira assembly has persistently omitted certain people: often subaltern individuals, and usually women and children. They also leave out certain kinds of cultural circulation, ones built on collective rather than individual authority. I will return to this. For now: tazkiras are not the only form that supply plural maps of border space, and other forms have incorporated other people and other networks better. Self-narrations of borderland lives often read very much like 'minor' narrative as described above. In this final section I present two examples: an autobiography by Ajmal Khattak, and a published oral history by Waris Khan.

Ajmal Khattak (1925-2010) is one of the best-known political forces in twentieth-century Pakistan, at least in Khyber Pakhtunkhwa. An activist whose early life was inseparable from the anticolonial movement, he was more inclined to socialism than most of the Khudai Khidmatgar movement was. He went on to be a leading figure in the National Awami Party (NAP), which was originally a series of networks among non-metropolitan socialist activists in Pakistan's geographical peripheries—NWFP, 
This is the accepted version of an article to be published by Taylor and Francis in South Asian History and Culture. Please refer to the published version when citing: http://www.tandfonline.com/loi/rsac20\#.V5Yrj krKUk

Accepted Version downloaded from SOAS Research Online: http://eprints.soas.ac.uk/22691/

Balochistan, Sindh, and East Bengal—all headed by the Deobandi communist and pir, Maulana Bhashani. At the same time, his poetic corpus is among the most important in modern Pashto, and one of the most formative articulations of the NWFP's secular and socialist stream of Pashtun nationalism. Like Taimoor Shahid writes regarding socialist Urdu poet Faiz Ahmed Faiz, though, it would be reductive to strip Khattak’s poetic world of the wider 'precapitalist' and 'precolonial' histories to which it was attached, just as it would be reductive to narrate his life only through his activism. ${ }^{\text {xxii }}$ And indeed, when he wrote a memoir Khattak produced not a political autobiography but a cultural one: Qīṣa Zamā da Adabī Zhwand, 'The Story of my Literary Life'.

An unbroken stream of fragmented images and episodes, the work evokes a number of possible trajectories for the reader, so what follows is one map. In the early portions of the book, Khattak tells the story of his involvement in the nationalist movement as a well-educated youth in a moderately prominent rural family of Nowshera in the agrarian heartland of the Peshawar Valley. It describes the progression of various pedagogical programs in the province including Khattak's own childhood education in the Persian and then English humanities; his subjectivation as a progressive nationalist youth in the theatre and poetry of local social reform groups; and his involvement in the creation of the Deobandi Haqqania madrasa. This institution later became notorious as a bastion of conservative militancy but in the 1940s, well before the populist turn exemplified by Maulana Mufti Mehmood, Khattak and other nationalists saw in Deobandism a pedagogical movement of self-critical intellectualism and social justice, and Deobandism began to pull in many students moving through formerly less centralized borderland educational networks. Finally, Khattak includes instances of how he and his colleagues engaged elite amateur poets and subaltern professional ones, and 'colonized' them with nationalism. Earlier frontier musha'iras, or 
This is the accepted version of an article to be published by Taylor and Francis in South Asian History and Culture. Please refer to the published version when citing: http://www.tandfonline.com/loi/rsac20\#.V5Yrj krKUk

Accepted Version downloaded from SOAS Research Online: http://eprints.soas.ac.uk/22691/

poetry gatherings, were contests, organized around professional poets' competitive search for patronage by demonstrating supremacy of intellect and wit against other poets; but Khattak and other elite nationalist youths worked with oral poets to transform musha'iras into sites of collaborative nationalist literary performance and pedagogy.

All in all, the first half of the memoir traces a broad trajectory of gathering up decentralized networks of culture into the gravitational field of organized anticolonial parties, away from borderland life. Perhaps not surprisingly this concentrated those networks' trajectories in the same places that empire established as its own political and economic centres. A mirroring of oppositional and hegemonic centres continues in the rest of the book, as Khattak describes the rise of the 1960s NAP in village space through literary activism, in a highly detailed account that also describes the rise of conservative and populist informal literary activism by religious networks.

But 'minor' asides throughout Khattak’s account may outweigh the narrative centre I produce above. For example Khattak notes how the very reason he, or anyone, was literate in Pashto alongside languages of power like Persian, Urdu, and English was the informal, usually unrecognized domain of female literacy that preserved Pashto's textual heritage in domestic spaces. He describes how women in his family networks and their own pedagogical spheres were his point of entry to the literate tradition in which he is now one of the best-known writers. Furthermore, as noted above he describes a counterhegemonic nationalization of Pashto poetic publics, as well as their celebration of youthful masculinity, altruistic and disciplined; but he describes this in quite ambivalent tones that contrast with the pleasure he found in other spheres including the domestic-literary one, and with the fact that he takes pains to commemorate their presence. And his account expresses barely concealed joy when recounting how more anarchic networks repeatedly irrupted into, and disrupted, 
This is the accepted version of an article to be published by Taylor and Francis in South Asian History and Culture. Please refer to the published version when citing: http://www.tandfonline.com/loi/rsac20\#.V5Yrj krKUk

Accepted Version downloaded from SOAS Research Online: http://eprints.soas.ac.uk/22691/

nationalist and colonial space-time alike. ${ }^{\text {xxiv }}$ Finally, Khattak describes cross-border involvement by Afghan intellectuals in Peshawar's intellectual life, a trend that allowed dialogue between the Afghan Wex Zalmiyan and NWFP activism. And this phase of activism, which Khattak describes with fluidity, coincided with less-centralized, districtto-district work that came in response to state violence and its renewed top-down fragmentations of local cultural space. In an era when Pakistan was a strong US ally against socialism, the ransacking of libraries amid crackdowns on formal expressions of quasi-left cultural life led to alliances with much less-disciplined networks. The two most popular oral poets with whom the Wex Zalmiyan and the NAP worked both bore the persona of malang, or wandering ascetic: a transvaluation of mundane politics into other worlds. Khattak's narrative voice, like his activism, is at its most nimble in its asides—when it relies on lateral, unpredictable alliances in sociocultural life.

This is also the case with $D a \bar{A} z \bar{a} d e y$ Tahrīk ('The Freedom Movement'), an oral history by Waris Khan. This account is remarkable in the way that it traces both the narrator's changing social awarenesses over time, and the changing networks of his region—also Nowshera District. Portions detailing Waris Khan's childhood are some of the most vivid in the book. It begins with his family’s migratory clan politics around the turn of the century, and Waris Khan's own memory mirrors a history of increasing state power as lineage narration gradually gives way to the settled village politics of the police station, revenue collectors, village headmen, peasants, and the aristocratic absentee landlord. It describes a great deal of local mobility as administration patterns shifted and railways were built, and details shifting local configurations of power as the anticolonial movement grew: all from a bottom-up perspective that relates the voices of tenant farmers; communist religious scholars; militant Hindu socialists; and more. It also incorporates wholesale a number of primary text fragments. 


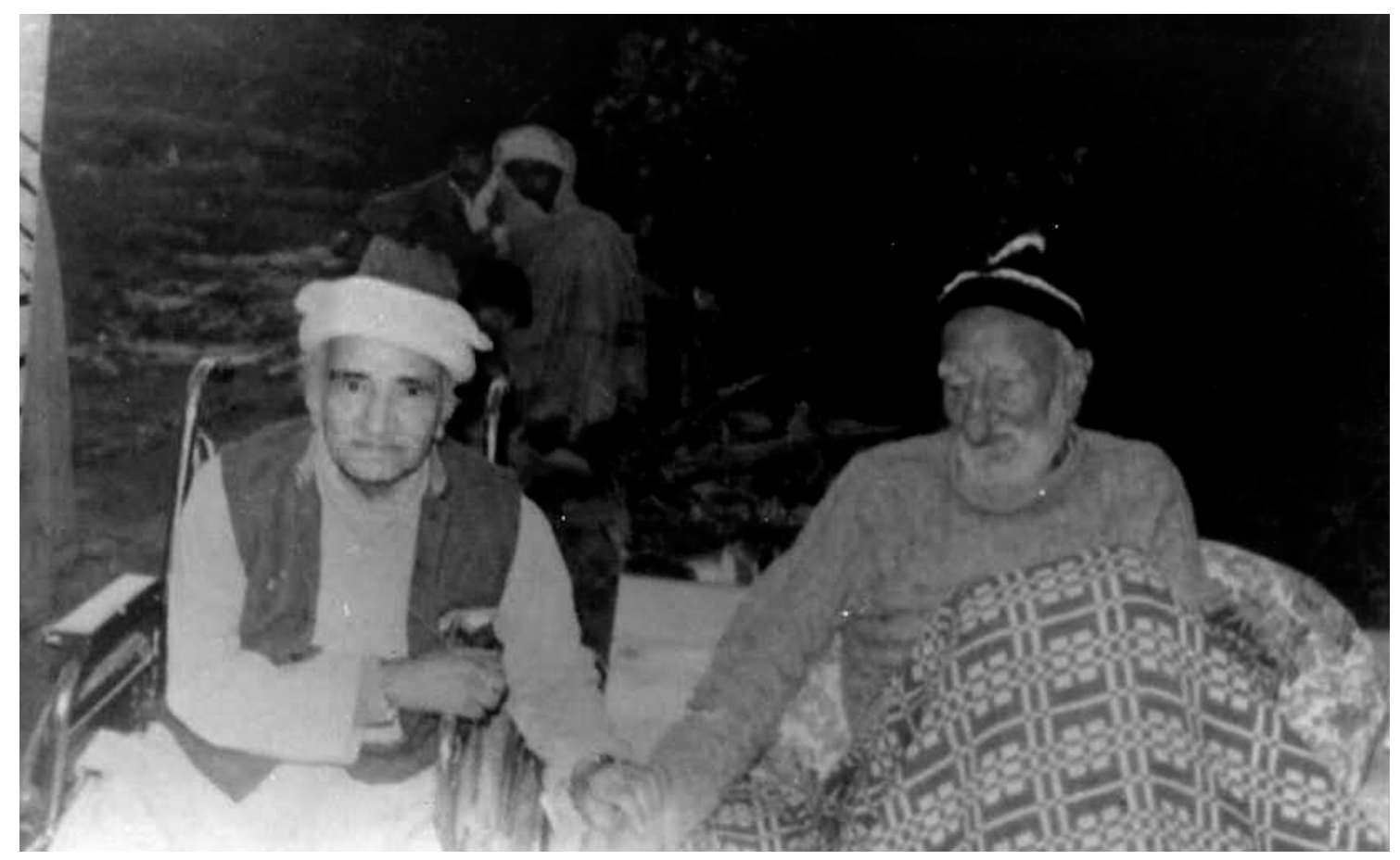

Figure 2. Waris Khan (at left); relatives (rear); Abdul Ghaffar Khan (at right). Photo courtesy of Waris Khan's family.

Like Khattak, Waris Khan repeatedly highlights actors that have been marginal to all but the most interesting Afghan tazkiras. It is, again, the women of the family who educate Waris in Pashto literacy; while these women also take a strong role in directing clan politics in his family of small landholders. He also recalls romantic characters who escape structural power: particularly memorable are the bandit Zarin Khan, who lived just over the border in the Tribal Districts, and the one-time wife of a powerful Afridi khan who ran off with Zarin and who rode into raids alongside him, carrying her own rifle. Alongside these occasionally appear quieter worlds like women’s shrine devotion, or the life of a female ascetic in Waris Khan's village. And Waris Khan himself writes from a liminal world rarely depicted. Stricken by polio as an infant, he was subjected to less discipline than his peers due to his disability. He describes how his rages, and he in general, became associated with possession by fairy-spirits (perayān). He also notes 
This is the accepted version of an article to be published by Taylor and Francis in South Asian History and Culture. Please refer to the published version when citing: http://www.tandfonline.com/loi/rsac20\#.V5Yrj krKUk

Accepted Version downloaded from SOAS Research Online: http://eprints.soas.ac.uk/22691/

how his disability and his association with the world beyond materiality kept him from being punished, when he first began working as a community organizer in the early days of the anticolonial movement.

Subsequent portions that form the main body of the book narrate such things from an external perspective as superstition, but the early portions narrate fairies, miraculous assistance from The Unseen, and other such phenomena, empathetically: much as Waris himself might have done at the time he is describing. Such experiences are seldom found in other accounts of NWFP. They are also difficult to find in the agent-centric genre of tazkiras, though Celebrities of NWFP is interesting in the speech its authors sometimes include. As with the author of the Haji Sahib entry in Celebrities of NWFP, dynamic 'traditions', anonymous collective voices, the transcendent and the immaterial, are perspectives that compose Waris Khan and they demand of him that he include them, even as his later self dismisses some of them in part. This category also includes collectively-circulated gnomic poems that punctuate the work. These he does not dismiss, but rather reproduces in their entirety as explanatory commentary.

In his preface to History as Mindscapes, an account from another set of South Asian foothills, historian Yogesh Raj argues why he chose annotated oral history, rather than microhistory or another approach, in narrating the Newar peasant movement in Nepal. His conclusion is a vision to which our autobiographers would be sympathetic:

[In writing about marginal histories it] is not sufficient to alter the scale (from the general to the particular) or to adjust the focus (from external constraints on an individual to her internal longings for 'going astray') of observation. [One must] listen to the chorus (the social history) in a voice (an individual in the contingent role of a narrator) that can only be heard against the refrain of the chorus. ${ }^{\mathrm{xxv}}$

To assemble oral histories that enable this, Raj promotes a collaborative biographic- 
This is the accepted version of an article to be published by Taylor and Francis in South Asian History and Culture. Please refer to the published version when citing: http://www.tandfonline.com/loi/rsac20\#.V5Yrj krKUk

Accepted Version downloaded from SOAS Research Online: http://eprints.soas.ac.uk/22691/

narrative-interpretive method: a fieldworker asks directed questions to elicit a more or less whole story, punctuated by narratives of particular incidents that allow streams of consciousness. But Waris Khan’s account, in its printed form, highlights both voice and chorus without a fieldworker's intervention. The noted historian Sayed Wiqar Ali Shah told me that when he prepared Waris Khan’s oral history for publication, he merely proofread a transcription and added a foreword for those who might have trouble with its meandering unbroken style. ${ }^{x x v i}$ Both Khattak and Waris Khan already envisioned their selves as a coming together of many distinct voices, highlighted in their distinctiveness. They import fragments of teleology only to show all the ways those teleologies fracture, but like tazkiras they maintain macro-textures. How does this intersect with intellectual and social life? Khattak was a professional literary intellectual but Waris Khan was not. All that this article describes, despite the academic language it describes it in, is merely an intuitive way for Waris Khan to conceive and organize history, having grown up in geopolitical and intellectual border worlds.

\section{Conclusion}

More than the basic information they conveyed, the pedagogical value of reading selections from Celebrities of NWFP and from Waris Khan's memoir with students was that they made us ask together 'What sort of sociopolitical context would give rise to texts like this? What would make these texts ideal vehicles, in form as much as in content, for intuitively understanding the history they represent? Why are these histories the way that they are?' But in trying to inhabit these texts, we appreciated something of how history feels in a region where transregional and local forces pull various parts of it, and parts of individuals, in so many differing directions-as well as a bit of the experience of navigating that multiplicity actively. In the latter, one is able to trace a 
This is the accepted version of an article to be published by Taylor and Francis in South Asian History and Culture. Please refer to the published version when citing: http://www.tandfonline.com/loi/rsac20\#.V5Yrj krKUk

Accepted Version downloaded from SOAS Research Online: http://eprints.soas.ac.uk/22691/

region that still constituted a decentralized form of salient selfhood, even while already diverse social fragments settled into unequal relationships with multiple distant concentrations of political, economic, and cultural power-empires-over centuries.

In producing Celebrities of NWFP, Fazal Rahim Marwat, a political scientist, chose to produce a tazkira with plural voices each broadly sympathetic to perspectives they represent, rather than a linear narrative. What results is an alternative kind of general history since 1900. Spatial and temporal ruptures, like the many administrative boundaries between Afghanistan and Punjab, or like the 1947 formation of Pakistan, are not absent. They are, however, just a small part of its web of connections. And what sort of project is it? The idea of tazkira as memorative communication is a powerful frame in the War on Terror era. From 2001 more parts of the NWFP were pulled in more directions than had been the case for almost a century: tied through militant networks to Punjab and Afghanistan, alongside higher-profile supporters; tied to Karachi and Afghanistan by transport networks boosted by NATO supply lines, as well as by labour markets and smuggling networks; tied politically through patronage by sections of the state under General Musharraf to the religious party coalition that ruled the province, in what looked like an intensified, more authoritarian replay of Maulana Mufti Mehmood’s relationship with Islamabad. Meanwhile, regions on the Afghan border bore the brunt of a reinvigorated security state. The spatiality of securitization, whether airstrikes or local roadblocks, fragmented social life locally. Finally, all my student acquaintances, during my fieldwork in Peshawar since 2006, narrated a rapidly increasing provincialization within a national public culture that often portrayed border ethnicities as premodern. As Manan Ahmed Asif argues, this all coincided with a new US-influenced phase in military relationships to the frontier: an attitude toward the Tribal Areas as an aboriginal terra nullius to be reformatted at will, rather than a place with complex and durable 
This is the accepted version of an article to be published by Taylor and Francis in South Asian History and Culture. Please refer to the published version when citing: http://www.tandfonline.com/loi/rsac20\#.V5Yrj krKUk

Accepted Version downloaded from SOAS Research Online: http://eprints.soas.ac.uk/22691/

histories. ${ }^{\text {xxvii }}$ However one views the causality of this situation, a situation scarcely remedied by renaming the North-West Frontier Province 'Khyber-Pakhtunkhwa', a number of defensive cultural projects arose within this context.

One initiative by Rajwali Shah Khattak in University of Peshawar, for which he conducted research at University of Pennsylvania while I was there, was a short-lived attempt to create a Pashto cultural canon as foundation for a discipline that Khattak called 'Rohology', based on an archaic word for the border region, 'Roh'. The canon of this discipline would form the core curriculum for the Pashto Department he chaired. It would distil the essence of early modern literary traditions to 'recover' an indigenous ethics and self-knowledge now fragmented by imported knowledge systems, western and otherwise. The use of a lost toponym as a label for the discipline illustrates his desire to recover fragmented spatialities too. And while Rohology was an academic project, the scholar Aamer Raza discusses how desires to recover a fictive Pashto ethos from before the War on Terror now mark mainstream Pashto poetic production and popular music too, a trend in conscious repudiation of the profusion of Taliban songs, conservative radio, and pro-establishment television that have polarized Pashto media culture in Pakistan. ${ }^{\text {xxviii }}$

This is also the time when Celebrities of NWFP was produced. Similar in its drive to construct, but without a romantic view of a more unified past, is the archival imagination of the modern tazkira, or the 'minor' autobiography. The examples here consume fragments of culture from all sources available and weave them into webs of interconnection rather than concentrations of authority. And this too, both a poetics and a practice, enjoyed public engagement throughout the time period discussed here. As I discuss elsewhere, the sufi-modernist poet Amir Hamza Shinwari once wrote: 
This is the accepted version of an article to be published by Taylor and Francis in South Asian History and Culture. Please refer to the published version when citing: http://www.tandfonline.com/loi/rsac20\#.V5Yrj krKUk

Accepted Version downloaded from SOAS Research Online: http://eprints.soas.ac.uk/22691/

My elders lay buried in the east - But I'm no sun, that I sink submerged in the west [...] I carry wisdom from past to future - I go on through my own present's twists and turns As long as I don't gather everything into a centre - I go with jirgas, district to district Even if I, Hamza, travel on pilgrimage to Mecca - I go with a caravan of Pashtuns. ${ }^{\text {xxix }}$

This evokes not just the jirga as an ad hoc decision-making council and site of local knowledge production, but Hamza’s involvement in the Ulasi Adabi Jirga, a collection of broadly leftist intellectuals who did indeed travel from district to district, engaging in live rural poetic public events during the Cold War-era, pro-US military dictatorship of Ayub Khan. It was a time when party organization and overtly political activism were impossible and what Pashto print existed at the time was government-sponsored and quietist. In this context, Ajmal Khattak suggests, the Jirga's groundwork was vital to the aforementioned National Awami Party later. In Hamza’s lines we have a meta-reference to border thinking that connected deliberate networking of epistemically diverse fragments like those in this article, to actual borderland social activism. And, like Madina Tlostanova argues in relation to post-Soviet Eurasia ${ }^{\mathrm{xxx}}$, the case here is not of ‘indigenous knowledges vs. Western-European modernity’ but of modern European coloniality overlapping with many systems of domination that occupy other spatialities and chronologies too-as illustrated in the case of Mufti Mehmood, and his fluctuating Deobandi spatialities and social concerns. Hamza's networked imagination emerges from life as a sufi intellectual and a cultural activist in a complex imperial borderland, colonizations of which did not begin or end with the British empire even during that empire’s formal rule. Intellectuals in the Afghan-Pakistan borderland have negotiated such complex dynamics for centuries. During that time 'indigenous' border knowledge has changed in content, but as a flexible practice it has held its own in the arms race. So border history and its genres of knowledge enjoy broad public engagement 
This is the accepted version of an article to be published by Taylor and Francis in South Asian History and Culture. Please refer to the published version when citing: http://www.tandfonline.com/loi/rsac20\#.V5Yrj krKUk

Accepted Version downloaded from SOAS Research Online: http://eprints.soas.ac.uk/22691/

here, and new work continues. In the world since 2001, border space continues fragmenting under new geopolitical considerations that seem to be enabling ever more violent forms of brokerage. Whether this violence is of state militaries or equally transregional militia networks or more mundane inequalities of political economy, those who seek to counteract such violence from all directions continue to choose epistemic heterogeneity that is holistic with positive transformation of societal fragments. For example? Let us return to Celebrities of NWFP. It was an intellectual intervention in the context described above, but a number of the individuals involved in that work were also involved directly or indirectly in building a new version of the Khudai Khidmatgar school system, successor to Haji Sahib’s: seeking to work with local knowledge as well as more commonplace educational systems to meet students in the worlds that they live in, training them to think and act autonomously from the violence colonizing the borderland from all sides while equipping them to engage wider worlds.

Paying attention to the 'unorthodox' genres described here contributes to work on decoloniality and the global humanities at large by offering new perspectives on major multi-front transregional struggles that define our current global moment. Paying closer attention reveals that border perspectives are most valuable when their full social presence is taken seriously as part of their epistemology. In my case this thinking all began with two personal facts. First, I conducted my doctoral fieldwork via informal networks that linked scholars in University of Peshawar and the Afghan Academy of Sciences to traditional tazkira historians like Bakhtani to small-town amateur historians and archivists. Second, I lacked extensive training in western humanities prior to beginning an Area Studies doctorate on the border of disciplines. This all led to my choice, unconscious at the time, to treat these networks not as objects of study but as disciplinary training; and to incorporate to my personality the wider worlds of emotion, 
This is the accepted version of an article to be published by Taylor and Francis in South Asian History and Culture. Please refer to the published version when citing: http://www.tandfonline.com/loi/rsac20\#.V5Yrj krKUk

Accepted Version downloaded from SOAS Research Online: http://eprints.soas.ac.uk/22691/

aesthetics, authority, and knowledge-forms that regulate those networks, just as I had done in adapting to life as a PhD student in Philadelphia. All that conflicted with a subsequent sense that I had to unlearn much of that, in favour of writing the way this article is written, in order to succeed as an 'academic' afterwards. As should have been clear, this article is not just an argument; it is an homage and a protest too.

But it is also an argument. Genres of knowledge and the networks they engage are part of larger processes of fragmentation and recomposition. Some 'mainstream' scholars in the Afghan-Pakistan borderland take this into account more often than may be appreciated. This can produce outputs that look more erratic than dominant academic life is accustomed to, but that may be more pedagogically valuable globally as well as locally, and intellectually more accessible to more people. What is the ultimate point? Research both inside and outside the region can work with this, rather than against it, but it requires collaborating with and contributing to border milieus rather than only writing about them. That does not necessarily require aligning with specific political interests or attaching to particular issues. Facilitating participative living tazkiraarchives instead of building exclusive narrative authority, for instance, could produce something like the digital collective Pad.Ma’s idea of deployable archives: active interventions in culture that might be 'a set of shared curiosities, a local politics, or epistemological adventure' that contribute to knowledge in an overall sense without much predetermined teleological direction. ${ }^{\text {xxxi }}$ Such projects could create reciprocity between, or blur lines between, scholar and society; while if done reflexively they could, like Celebrities, be targeted to create multidimensional knowledge responsive to multiple local social engagements.

Involvement of global academic life in that sort of critical project could help link this border domain to others in the global south, rather than only appropriating it in a 
This is the accepted version of an article to be published by Taylor and Francis in South Asian History and Culture. Please refer to the published version when citing: http://www.tandfonline.com/loi/rsac20\#.V5Yrj krKUk

Accepted Version downloaded from SOAS Research Online: http://eprints.soas.ac.uk/22691/

one-sided fashion—furthering what Dussel has called 'incorporative solidarity' xxxii. In another direction entirely, creating institutional and intellectual space for students and programmes to experiment with their exposure to border history, rather than suppressing it, would help revitalize disciplines. This is also one way in which area studies departments can move beyond their traditional cores and position themselves to innovate in the current global academic environment. But whatever the case, articles like this one may ultimately have the most impact if they successfully argue their demise. Can we get on with building genres that more intuitively represent the phenomena they set out to represent, not despite but because they either incorporate seriously our own investment in already-existing networks, or drive scholars to invest more of ourselves in more of them?

Green, ‘A History of Afghan Historiography’, 1.

See Bashir, 'On Islamic Time’.

Bashir, ‘On Islamic Time’, 543.

Deleuze and Guattari, A Thousand Plateaus, 4.

Qadir, Sayyid Ahmad Barailvi.

See especially Rauf, 'Socio-educational reform movements.'

Rauf, ibid., 34-35.

Trouillot, Silencing the Past, 19.

On chapbook culture: Heston, 'Footpath Poets...’ Haroon, Frontier of Faith, 32-33.

Hopkins and Marsden, Fragments of the Afghan Frontier, 111-12 
This is the accepted version of an article to be published by Taylor and Francis in South Asian History and Culture. Please refer to the published version when citing: http://www.tandfonline.com/loi/rsac20\#.V5Yrj krKUk

Accepted Version downloaded from SOAS Research Online: http://eprints.soas.ac.uk/22691/

xiii For a recent articulation of the concept in English see Dussel, 'A New Age in the

History of Philosophy’.

xiv See especially Mignolo, 'On Pluriversality'

xv Hermansen and Lawrence, 'Indo-Persian Tazkiras ...', 160.

xvi For the most useful accounts see Green, ed., Afghan History through Afghan

Eyes, and Green and Arbabzadah, eds., Afghanistan in Ink.

xvii Benawa, Osani Likwal vol. 1, 295-96.

xviii Caron, 'Reading the Power of Printed Orality’, esp. 176-77; 183-84; fn. 51.

xix $\quad$ Marwat and Toru, eds., Celebrities of NWFP.

xx Guha, 'The Politics of Identity and Enumeration...'

xxi For this argument related to the Pakistani Tribal Areas see Alia Qaim, Political

Economy of Development.

xxii Deleuze and Guattari, Kafka, 22.

xxiii Shahid, 'The Politics of Enchantment', 215.

xxiv For an example see Caron, 'Taliban, Real and Imagined', 66-67.

xxv $\quad$ Raj, History as Mindscapes, 5.

xxvi Shah, personal communication, 5 May 2016.

xxvii Asif, 'Adam’s Mirror.'

xxviii Raza, 'Voices of Resistance’.

xxix See Caron, 'The Lives of Amir Hamza Shinwari’.

xxx See especially Tlostanova, 'How can the decolonial project become the ground...'

xxxi Pad.ma, 'Ten Theses on the Archive'

xxxii See Dussel 'Eurocentrism and Modernity’. 
This is the accepted version of an article to be published by Taylor and Francis in South Asian History and Culture. Please refer to the published version when citing: http://www.tandfonline.com/loi/rsac20\#.V5Yrj krKUk

Accepted Version downloaded from SOAS Research Online: http://eprints.soas.ac.uk/22691/ 
Bibliography:

Asif, Manan Ahmad. “Adam’s Mirror: The Frontier in the Imperial Imagination.” Economic \& Political Weekly 46, no. 13 (March 26, 2011): 60-65.

Bashir, Shahzad. “On Islamic Time: Rethinking Chronology in the Historiography of Muslim Societies.” History \& Theory 53, no. 4 (December 2014): 519-44. doi:10.1111/hith.10729.

Bēnawā, ‘Abd al-Ra’ūf. Ōsan̄̄ Līkwāl (3 vols.). Kabul: Da Mațb̄‘ātō Mustaqil Riyāsat, 1961-1966.

Bēnawā, ‘Abd al-Ra’ūf. Da Afghānistān Nūmiyālī (4 vols.). Kabul: Da Mațbū'ātō Mustaqil Riyāsat, 1974-1981.

Caron, James. “The Lives of Amir Hamza Shinwari: On Personal Histories against an Imperial Border.” Tanqeed $\mid a$ Magazine of Politics and Culture 10 (2015): 43-53.

Caron, James. "Reading the Power of Printed Orality in Afghanistan: Popular Pashto Literature as Historical Evidence and Public Intervention.” Journal of Social History 45, no. 1 (2011): 172-94.

Caron, James. “Taliban, Real and Imagined.” In Bashir and Crews, eds. Under the Drones. Harvard University Press, 2012.

Deleuze, Gilles, and Félix Guattari. A Thousand Plateaus. Minneapolis: University of Minnesota Press, 1987.

Deleuze, Gilles, and Félix Guattari. Kafka: Towards a Minor Literature. Minneapolis: University of Minnesota Press, 1975.

Dussel, Enrique. “A New Age in the History of Philosophy: The World Dialogue between Philosophical Traditions.” Philosophy \& Social Criticism 35, no. 5 (June 2009): 499-516.

Dussel, E., 1993. Eurocentrism and Modernity (Introduction to the Frankfurt Lectures). boundary 2 20, 65-76.

Green, Nile. “A History of Afghan Historiography.” 1-51 in Green, ed., Afghan History Through Afghan Eyes. New York: Oxford University Press, 2016.

Green, Nile, ed. Afghan History Through Afghan Eyes. New York: Oxford University Press, 2016.

Green, Nile, and Nushin Arbabzadah, eds. Afghanistan in Ink: Literature Between Diaspora and Nation. Columbia University Press, 2012.

Guha, Sumit. "The Politics of Identity and Enumeration in India C. 1600-1990.” Comparative Studies in Society and History 45, no. 1 (2003): 148-67.

Haroon, Sana. Frontier of Faith: Islam in the Indo-Afghan Borderland. C. Hurst \& Co, 2007.

Hermansen, Marcia, and Bruce B. Lawrence. “Indo-Persian Tazkiras as Memorative Communications.” 149-75 in D. Gilmartin and B. Lawrence, eds., Beyond Turk and Hindu: Rethinking Religious Identities in Islamicate South Asia. Gainesville, FL: University Press of Florida, 2000.

Heston, Wilma. "Footpath Poets of Peshawar.” 305-43 in Appadurai, Korom, and Mills, eds., Gender, Genre, and Power in South Asia Expressive Traditions. Philadelphia: University of Pennsylvania Press, 1991.

Hopkins, Benjamin D., and Magnus Marsden Fragments of the Afghan Frontier. New York: Columbia University Press, 2012.

Marwat, Fazal Rahim, and Parvez Toru. Celebrities of NWFP. Peshawar: Pakistan Study Centre, 2005.

Mignolo, Walter D. “On Pluriversality”. http://waltermignolo.com/on-pluriversality/. 20 October, 2013. [accessed 6 May, 2016]

Pad.ma. 'Ten Theses on the Archive'. 2010. https://pad.ma/texts/padma:10_Theses_on_the_Archive [accessed 7 May, 2016] 
Qadir, Altaf. Sayyid Ahmad Barailvi: His Movement and Legacy from the Pukhtun Perspective. New Delhi: SAGE, 2015.

Qadir, Altaf. Reforming the Pakhtuns and Resisting the British: An Appraisal of the Haji Sahib Turangzai's Movement. Islamabad: National Institute of Historical and Cultural Research, Quaid-e-Azam University, 2015.

Qaim, Alia. “The Political Economy of Development in Federally Administered Tribal Areas (FATA) of Pakistan.” PhD Thesis, Royal Holloway, University of London, 2016.

Raj, Yogesh. History as Mindscapes A Memory of the Peasants' Movement of Nepal. Kathmandu: Martin Chautari, 2010.

Rauf, Abdul. "Socio-Educational Reform Movements in NWFP - A Case Study of Anjuman-i Islahul Afaghina." Pakistan Journal of History and Culture 27, no. 2 (2006): 31-60.

Raza, Aamer. "Voices of Resistance: Pashto Poetry as Bulwark against Extremism.” In Ayub Jan and Shahida Aman, eds. The Dynamics of Change in Conflict Societies: Pakhtun Region in Perspective. Peshawar: Peshawar University and Hanns Seidel Stiftung, 2014.

Shah, Sayed Wiqar Ali. Ethnicity, Islam and Nationalism: Muslim Politics in the North-West Frontier Province, 193747. Karachi: OUP Pakistan, 1999.

Shahid, Taimoor. "The Politics of Enchantment: Remapping the Precapital in Faiz Ahmad Faiz’s Postcolonial Poetry.” The Annual of Urdu Studies 28 (2013): 215-48.

Tlostanova, Madina. 'How can the decolonial project become the ground for the decolonial humanities? A few reflections from the "vanished" second world.' Workshop paper: Duke University Center for Global Studies and the Humanities, 'Reflections on the Decolonial Option and the Humanities: an international dialog'. 21 Feb., 2008. http://www.jhfc.duke.edu/globalstudies/Tlostanova_how\%20can\%20the\%20decolonial\%20project.pdf [Accessed 05 May 2016].

Trouillot, M.-R. Silencing the Past: Power and the Production of History. Boston: Beacon Press, 1997.

Yépez, Heriberto. “La Frontera Como Falla.” Metapolítica 11, no. 52 (April 2007): 49-53. 